\title{
1 Earlier Physical Therapy Input is Associated with a Reduced Length of \\ 2 Hospital Stay and Reduced Care Needs on Discharge in Frail Older
}

\section{Inpatients: An Observational Study}

Peter J Hartley ${ }^{1}$ PT MSc; Victoria L Keevil ${ }^{2,3}$ MD PhD, Ledia Alushi ${ }^{1}$ PT BSc; Rebecca L Charles ${ }^{1}$ PT MSc; Eimear B Conroy ${ }^{1}$ PT BSc; Patricia M Costello ${ }^{1}$ PT MSc; Becki Dixon ${ }^{1}$ PT BSc; Aida M Dolinska-Grzybek ${ }^{1}$ PT BSc; Diana Vajda ${ }^{1}$ PT BSc; Roman RomeroOrtuno $^{2,3} \mathrm{MD} \mathrm{PhD}$

\footnotetext{
${ }^{1}$ Department of Physiotherapy, Addenbrooke's Hospital, Cambridge, United Kingdom; ${ }^{2}$ Department of Medicine for the Elderly, Addenbrooke’s Hospital, Cambridge, United Kingdom; ${ }^{3}$ Clinical Gerontology Unit, Department of Public Health and Primary Care, University of Cambridge, Cambridge, United Kingdom
}

\section{ABSTRACT}

6 Background and Purpose: Pressures on hospital bed occupancy in the English National

7 Health Service (NHS) have focused attention on enhanced service delivery models and

8 methods by which physical therapists might contribute to effective cost savings, while

9 retaining a patient-centered approach. Earlier access to physical therapy may lead to better

10 outcomes in frail older inpatients, but this has not been well studied in acute NHS hospitals.

11 Our aim was to retrospectively study the associations between early physical therapy input

12 and length of hospital stay (LOS), functional outcomes and care needs on discharge.

13 Methods: This was a retrospective observational study in a large tertiary university NHS

14 hospital in the United Kingdom. We analyzed all admission episodes of people admitted to

15 the Department of Medicine for the Elderly wards over 3 months in 2016. Patients were 
categorized into 2 groups: those examined by a physical therapist within 24 hours of

17 admission and those examined after 24 hours of admission.

The outcome variables were: LOS (days), functional measures on discharge (Elderly

19 Mobility Scale and walking speed over 6 meters), and the requirement of formal care on

20 discharge. Characterization variables on admission were: age, gender, existence of a formal

21 care package, pre-admission abode, the Clinical Frailty Scale, Charlson Comorbidity Index,

22 the Emergency Department Modified Early Warning Score, C-reactive protein level on

23 admission, and the 4-item version of the Abbreviated Mental Test.

24 The association between the delay to physical therapy input and LOS before

25 discharge home was evaluated using a Cox proportional hazards regression model.

26 Results and Discussion: There were 1022 hospital episodes over the study period. We

27 excluded 19 who were discharged without being examined by a physical therapist. Of the

28 remaining 1003, 584 (58.2\%) were examined within 24 hours of admission (early

29 assessment), and 419 (41.8\%) after 24 hours of admission (late assessment).

$30 \quad$ The median (interquartile range: IQR) LOS of the early assessment group was 6.7

31 (3.1-13.7) versus 10.0 (4.2-20.1) days in the late assessment group, $\mathrm{P}<0.001$. The early

32 assessment group was less likely to require formal care on discharge: $n=110$ (20.3\%) versus

$33 \mathrm{n}=105$ (27.0\%), $\mathrm{P}=0.016$. No other statistically significant differences were seen between

34 the 2 groups.

35 In the unadjusted Cox proportional hazards model, the hazard ratio for early

36 assessment compared to late assessment was 1.29 (95\% confidence interval: 1.12-1.48, P <

37 0.001). Early assessment was associated with a 29\% higher probability of discharge to usual

38 residence within the first 21 days after admission, compared to late assessment. Adjustment

39 for possible confounding variables increased the hazard ratio: $1.34(1.16-1.55) \mathrm{P}<0.001$. 
40 Conclusions: Early physical therapy input was associated with a shorter LOS and lower odds

41 of needing care on discharge. This may be due to the beneficial effect of early physical

42 therapy in preventing hospital-related deconditioning in frail older adults. However, causality

43 cannot be inferred and further research is needed to investigate causal mechanisms.

44

45 Key Words: Physical therapy, Outcome assessments, England, Older adults, Acute care 


\section{INTRODUCTION}

47 Frail older people have increased vulnerability to poor resolution of homeostasis following a

48 stressor event, ${ }^{1}$ such as an illness or fall necessitating an admission to hospital. In frail older

49 adults, hospitalization is associated with longer length of stay (LOS), ${ }^{2,3}$ and sometimes it can

50 lead to physical deconditioning and loss of functional ability., ${ }^{4,5}$

51 Pressures on hospital bed occupancy in the English National Health Service (NHS)

52 are increasing: over the period of 2006/07 to 2012/13, hospitals have reported increases in

53 admissions from 12.6 million per year to 14.6 million per year, an increase of $16 \%{ }^{6}{ }^{6}$ These

54 pressures have in part been driven by an increase in the population of frail older people, ${ }^{7}$ and

55 have focused attention on enhanced service delivery models and potential methods by which

56 geriatric physical therapists might contribute to effective cost savings, while retaining a

57 patient-centered approach. Our previous work suggested that higher physical therapy

58 frequency is associated with shorter LOS and greater functional recovery in hospitalized frail

59 older adults. ${ }^{8}$ Few studies investigated the effect of early mobilization on LOS in similar

60 populations, ${ }^{9,10}$ as well as the effect of physical therapy within the emergency department in

61 reducing admissions. ${ }^{11}$ An important distinction exists between early physical therapy

62 assessment and early mobilization. Assisting mobilization is often an intervention carried out

63 by a physical therapist, but by no means exclusively. Physical therapy assessment includes

64 assessment of the patient's impairments, activity limitations, and social situation. The

65 information ascertained from the assessment is used to devise a management plan to optimise

66 physical functioning and facilitate discharge from hospital. Few studies have investigated

67 early physical therapy assessment on LOS, functional outcomes and care needs on discharge.

68 Our aim was to study these associations using a retrospective observational design. We

69 hypothesized that early assessment may reduce LOS through earlier optimization of physical

70 functioning and reduce the need for care on discharge. 


\section{METHODS}

\section{Setting and participants}

74 This was a retrospective observational study in a large tertiary university NHS hospital in the

75 United Kingdom. We analyzed all admission episodes of people admitted to the Department 76 of Medicine for the Elderly wards between $2^{\text {nd }}$ May and $26^{\text {th }}$ Aug 2016. Patients who were

77 discharged without being examined by a physical therapist were excluded.

78

\section{Measures}

80 Anonymous routinely collected clinical data was obtained from the hospital electronic

81 medical records. Most data was collected from running an electronic report of variables of

82 interest. Other data was manually searched in the patients' electronic medical records by a

83 member of the physical therapy team, and verified independently by a second member. All

84 measures used in this service evaluation audit were routinely collected as part of normal

85 clinical care.

86 The exposures that we investigated were: early assessment by a physical therapist (i.e.

87 within 24 hours of admission to hospital) and late assessment (i.e. after 24 hours). The

88 definition of assessment did not take into account whether any intervention had been carried

89 out. The definition of early and late was arbitrarily set, although the policy in our Department

90 of Medicine for the Elderly is that every patient should be examined by a physical therapist

91 on the day of admission. A physical therapist is employed at the weekend to assess patients

92 admitted to the Department of Medicine for the Elderly wards, this includes those patients

93 admitted on a Friday, Saturday or Sunday.

94 The outcome variables were: LOS (days), the Elderly Mobility Scale (EMS), ${ }^{12}$

95 walking speed over 6 meters (meters/second), and the need for a new formal care package on 
96 discharge (yes or no) or new institutionalization. Information on in-patient mortality was also 97 collected.

The Elderly Mobility Scale is a 20-point ordinal scale for the assessment of function

99 in frail older patients ${ }^{12,13}$ (worst: 0 points; best: 20 points). The scale includes the assessment

100 of balance, mobility and ability to change body positions (e.g. from lying to sitting). The

101 inter-rater reliability of the Elderly Mobility Scale has been reported as $\mathrm{r}=0.88(\mathrm{P}<0.001)$,

102 and it has good convergent validity with the Barthel Index $(r=0.787, \mathrm{P}<0.001) .{ }^{13}$ The

103 Elderly Mobility Scale (which includes walking speed over 6 meters) is routinely measured

104 by Department of Medicine for the Elderly physical therapists on initial assessment and on

105 day of discharge from hospital.

106 A new formal care package on discharge is defined as new care provided by an

107 external care agency as opposed to informal arrangements of support with family or friends.

108 Patients are discharged home once they are deemed clinically fit for discharge by the multi-

109 disciplinary team and any social support required is in place. New institutionalization is

110 defined as discharge to a care home when patients had been admitted from home.

111 Admission variables collected for descriptive purposes were: age, gender, the

112 existence of a formal care package on admission (yes or no), number of falls in past twelve

113 months, whether the patient had daily contact with a family member or friend (yes/no, as

114 reported by the patient or a next of kin), pre-admission abode, the Clinical Frailty Scale

115 (CFS), ${ }^{14}$ the Charlson Comorbidity Index (non-age adjusted), ${ }^{15}$ specific co-morbidities, the

116 Emergency Department Modified Early Warning Score (ED-MEWS, highest recorded in the

117 ED), ${ }^{16}$ C-reactive protein (CRP) level on admission, and the 4-item version of the

118 Abbreviated Mental Test (AMT4). ${ }^{17}$

119 The CFS has been routinely collected in our center since 2013, thanks to a local

120 Commissioning for Quality and Innovation (CQUIN) scheme 
121 (https://www.england.nhs.uk/nhs-standard-contract/cquin/) that mandated that all patients

122 aged 75 years or over admitted to the Hospital via the emergency pathway be screened for

123 frailty using the CFS within 72 hours of admission. Our center uses the 9-point CFS

124 (http://geriatricresearch.medicine.dal.ca/clinical_frailty_scale.htm). The reported inter-rater

125 reliability of the CFS is high with an intra-class correlation coefficient $0.97(\mathrm{P}<0.001)$, and

126 it has high convergent validity with the Frailty Index (Pearson coefficient $0.80, \mathrm{P}<0.01$ ) ${ }^{14}$

127 The Charlson Comorbidity Index (CCI) is based on patients' diagnoses as coded by

128 the World Health Organization's International Classification of Diseases $\left(10^{\text {th }}\right.$ version). The

129 CCI has been validated for use in in acutely hospitalized older adults, with areas under the

130 receiver operating characteristic curve to predict mortality of 0.66 at 3 months after

131 admission, 0.70 at 1 year, and 0.73 at 5 years. ${ }^{18}$

132 ED-MEWS scores are routinely collected by nursing staff in ED, and are considered

133 as a measure of acute illness severity. ${ }^{16}$ Our ED-MEWS and its scoring protocol are shown in

134 Table 1. An ED-MEWS score of 4 or more has been shown to be an independent predictor of 135 survival time (HR $=2.87,95 \%$ CI: $2.27-3.62, \mathrm{P}<0.001) .{ }^{19} \mathrm{C}$-reactive protein is a measure of

136 acute inflammation and is a recognized clinical measure of illness severity. ${ }^{20,21}$

137 The 4-item version of the Abbreviated Mental Test (AMT4) ${ }^{17}$ is routinely collected in

138 our center as part of a Dementia/Delirium CQUIN, which aims at detecting cognitive

139 impairment on admission to hospital. The AMT4 consists of 4 questions regarding the

140 patient's age, date of birth, the place that the person is currently located, and the current year.

141 The AMT4 score showed a statistically significant correlation with AMT score (Somers' d

142 statistic $0.90, \mathrm{P}<0.001) .{ }^{17}$

\section{Analyses}

145 Anonymized data was analyzed with IBM SPSS Statistics (version 22) software. Descriptive 
146 statistics were given as count (with percentage) or mean (with standard deviation: SD). For 147 continuous variables with a non-normal distribution, we reported median values with inter-

148 quartile ranges (IQR). Differences in the characteristics and outcomes of patients who

149 received early versus late physical therapy were evaluated using unpaired Student's t, chi-

150 squared or Mann-Whitney tests as appropriate. Missing values for each variable were

151 reported and treated as missing in each analysis. The level of statistical significance was set

152 at $\mathrm{P}<0.05$, and $\mathrm{P}<0.1$ was considered as statistical trend.

153 The association between the delay to physical therapy assessment and LOS was evaluated

154 using a Cox proportional hazards regression model. Patients admitted from a residential or

155 nursing home were excluded, and we included only those admitted from their own home.

156 Cox proportional hazards regression can account for the censoring of some participants who

157 do not experience the outcome within the study timeframe. This type of regression is most

158 commonly used to analyze survival data, where time to an event such as death or recurrence

159 of disease is modeled. In this study the 'event' was set as 'Discharge to Usual Residence'

160 within 21 days of hospital admission. Those who were not discharged to their usual residence

161 within 21 days were censored. To differentiate those who died and to prevent informative

162 censoring (i.e. at death) those who died were given an imputed LOS value of 21.01 days (i.e.

163 just over the maximum follow-up time allowed) and were therefore only censored at the end

164 of the study. The decision to choose 21 days as the cut-off was made because LOS had a very

165 skewed distribution with a long tail at the right end. A preliminary analysis of our data

166 showed that by 21 days over $80 \%$ of patients had been discharged from the hospital. Clinical

167 experience tells us that the majority of patients not discharged by this point are considered

168 'stranded' that is, factors not related to the patient's physiological status keep them in the

169 hospital. They can be delayed from going home for a number of non-patient related reasons

170 such as requiring care but none being available, or requiring institutionalization but there not 
171 being any places in their locality. By choosing the 21-day cut-off point we aimed to focus on

172 the impact of physical therapy on the early optimization of patients' physiological status and

173 functional abilities. In this study the hazard ratio represents the likelihood of being

174 discharged back to usual residence within 21 days of admission.

175

176 Ethics Approval

177 This study was registered as a service evaluation audit with our center's Safety and Quality

178 Support Department (Project Register Number 5205). Formal confirmation was received that 179 approval from the Ethics Committee was not required.

\section{$181 \quad$ RESULTS}

182 There were 1022 hospital episodes over the study period. Of those, we excluded 19 who were

183 discharged without being examined by a physical therapist. Of the remaining 1003, 584

184 (58.2\%) were examined within 24 hours of admission (early assessment), and 419 (41.8\%)

185 after 24 hours of admission (late assessment).

186 Patient admission characteristics are reported in Tables 2 and 3. No significant

187 differences were seen between the 2 groups, except that the following comorbidities were

188 more frequent in the late assessment group: myocardial infarction, congestive heart failure,

189 metastatic cancer and depression.

190 Patient outcomes are reported in Table 4. The median (IQR) LOS of the early

191 assessment group was $6.7(3.1-13.7)$ versus $10.0(4.2-20.1)$ days in the late assessment

192 group $(\mathrm{P}<0.001)$. The other significant difference between the 2 groups was the number of

193 patients requiring a new package of care on discharge: $110(20.3 \%)$ in the early assessment

194 group, versus $105(27.0 \%)$ in the late assessment group $(\mathrm{P}=0.016)$. There were no other

195 statistically significant differences, although there was a trend observed with those in the 
early assessment group being apparently less likely to require new institutionalization on

197 discharge: $4.1 \%$ versus $6.7 \%, \mathrm{P}=0.073$.

The result of the Cox proportional hazards regression model studying the association

199 between delay to physical therapy and discharge to usual residence (excluding those already

200 living in a residential or nursing home prior to admission) is presented in Figure 1. The

201 hazard ratio (HR) for early assessment compared to late assessment was 1.29 (95\%

202 confidence interval: 1.12-1.48, $\mathrm{P}<0.001$ ) and can be interpreted as a $29 \%$ increase in

203 the probability of discharge to usual residence for those in the early assessment group

204 compared to those in the late assessment group. Table 5 presents the results of the Cox

205 regression, with different covariates added to the model. After controlling for age, sex, ED-

206 MEWS, Charlson Comorbidity Index and the Elderly Mobility Scale score on admission,

207 results were still significant: 1.34 (95\% CI: $1.16-1.55), \mathrm{P}<0.001$.

208

209 DISCUSSION

210 This retrospective observational study examined the association between early physical

211 therapy assessment and hospital and functional outcomes in acutely hospitalized older adults.

212 In our busy NHS geriatric wards, the majority of eligible patients (58.2\%) were examined by

213 the physical therapist within 24 hours of admission. Early physical therapy assessment was

214 associated with a shorter length of stay, reduced need for care on discharge, a trend towards

215 reduced new institutionalization and equal amount of functional recovery by discharge.

216 Causality cannot be inferred from this observational study, but results would suggest it is

217 worth investigating in prospective studies whether physical therapy intervention within the

218 first 24 hours of admission is beneficial. Our findings are in keeping with previous work

219 reporting an association between early mobilization and reduced LOS, ${ }^{9,10}$ and with previous

220 evidence that early physical rehabilitation care for acutely hospitalized older adults may lead 
221 to functional benefits and can be safely executed. ${ }^{22,23}$ Indeed, in other specialty areas such as 222 stroke it appears that mobilization within 24 hours of admission has become the 'norm' in 223 recent years. ${ }^{24}$ The reason why there was no difference in functional outcomes may be due to 224 discharge criteria; for a patient to be deemed clinically fit for discharge, their physical

225 function and amount of recovery is a factor taken into account by the geriatric

226 multidisciplinary team (MDT). In the majority of cases, the MDT look for the patient to be 227 close to their pre-admission level of function. Given the similarities in baseline characteristics 228 it is probable that both groups had the same amount of recovery to be made, and the longer

229 LOS seen in the late assessment group may be in part due to the slower functional recovery. $230 \quad$ The reasons as to why some patients were not seen within 24 hours of admission are 231 not clear from our design. Although Table 2 reports no significant differences between 232 groups in key patient characteristics, an interesting finding is that specific comorbidities such 233 as acute myocardial infarction, congestive heart failure, metastatic cancer and depression 234 seemed to be more prevalent in the late assessment group (Table 3). It is possible that in 235 some cases, the lateness of the physical therapy assessment may have been due to a medical 236 contraindication arising from acute cardiovascular instability. In other cases, the delay in 237 seeing the therapist may have been due to patients being too unwell or psychologically averse 238 to therapy (e.g. depressed or withdrawn). A limitation is that our database did not contain the 239 principal diagnosis for the admission, and this may have shed light into these subtle patient

240 differences. Otherwise, patients in the 2 categories were treated by similar multi-disciplinary

241 teams and we have no reasons to believe that the care received by the 2 groups differed.

242 However, we cannot exclude the effects of day-to-day variations in staffing and number of 243 admissions.

244 The main limitation of our study is the lack of randomization or blinding. As a result, 245 we cannot make any assertions regarding the causality of our findings, definitive statements 
246 of association, or the generalizability beyond our hospital. In addition, we only recorded 247 measures of function on admission and discharge. Further measures at other time points may

248 have given us an indication of the rate of functional recovery. All we can infer regarding

249 functional change is that both groups had a similar overall amount of recovery and the earlier

250 discharge in the early assessment group did not appear to represent risk-taking behavior by

251 clinicians (i.e. patients were not discharged earlier without having made a similar amount of

252 functional recovery as those in the late assessment group). We have isolated one aspect of the

253 'dose' of physical therapy input, the AVERT studies have highlighted the potential

254 importance of studying other aspects of the dose of physical therapy input, such as frequency

255 and duration. ${ }^{25} \mathrm{~A}$ limitation of routinely collected clinical data obtained from the hospital

256 electronic medical records is the risk of bias characteristic of retrospective studies.

257 Patients admitted to Department of Medicine for the Elderly wards undergo inpatient

258 comprehensive geriatric assessment. There is evidence that frail patients undergoing

259 comprehensive geriatric assessment in the hospital are more likely to be alive and at home

260 after hospital discharge. ${ }^{26}$ Our study suggests that physical therapy is likely a key part of

261 comprehensive geriatric assessment, and earlier input may be associated with better hospital

262 outcomes. The reasons for reduced hospital LOS are not clear and causality cannot be

263 inferred from our findings. Frail older patients are particularly susceptible to functional loss

264 during acute illness via direct inflammatory damage to the musculoskeletal and central

265 nervous systems. ${ }^{27-29}$ Furthermore, lack of physical activity and bed rest seen in this

266 population ${ }^{30,31}$ has been shown to result in rapid muscle atrophy. ${ }^{32}$ It may be that early

267 physical therapy assessment encourages increased physical activity, by direct intervention,

268 education and improving patient confidence with self-administered exercise, and as a result

269 reduces hospital deconditioning leading to faster functional recovery. Interestingly, our data

270 in Table 4 demonstrates reduced need for care on discharge and a trend for reduced numbers 
271 of patients in the early assessment group who required a new package of care on discharge.

272 This may potentially represent reduced deconditioning in the early assessment group.

273 Our findings may not be generalizable beyond our hospital, but they make a

274 worthwhile contribution to what the UK Medical Research Council defines as the

275 'development phase' of the development and evaluation of a complex intervention, ${ }^{33}$ in this

276 case the acute care of frail older patients. Prospective interventional studies are necessary to

277 clarify the importance of early physical therapy input in the outcomes of hospitalized frail

278 older people, including the prevention of hospital-related deconditioning.

279

\section{CONCLUSION}

281 We set out to investigate the association of early physical therapy input with length of stay,

282 functional outcomes and care needs on discharge. We found that there was an association

283 with reduced length of stay, need for formal care on discharge from hospital and a trend

284 towards reduced new institutionalization on discharge from hospital. This may be due to

285 preventing hospital deconditioning, however further prospective research is needed to

286 establish causality and if appropriate investigate causal mechanisms.

287

288 Funding

289 Permission to use the CFS was obtained from the principal investigator at Geriatric Medicine

290 Research, Dalhousie University, Halifax, Canada. The study was in part conducted during a

291 research training fellowship for Peter Hartley funded by Addenbrooke’s Charitable Trust and 292 the Cambridge Biomedical Research Centre.

293

294

295 Acknowledgements 
296 We wish to thank all the members of the Department of Medicine for the Elderly teams in our 297 hospital, without whom this initiative would have not been possible. Licensed access to the 298 Trust's information systems is also gratefully acknowledged. 


\section{REFERENCES}

1. Clegg A, Young J, Iliffe S, Rikkert MO, Rockwood K. Frailty in elderly people. Lancet. 2013;381(9868):752-762.

2. Basic D, Shanley C. Frailty in an older inpatient population: using the clinical frailty scale to predict patient outcomes. J Aging Health. 2015;27(4):670-685.

3. Wallis SJ, Wall J, Biram RW, Romero-Ortuno R. Association of the clinical frailty scale with hospital outcomes. QJM. 2015;108(12):943-949.

4. Hoogerduijn JG, Buurman BM, Korevaar JC, Grobbee DE, de Rooij SE, Schuurmans MJ. The prediction of functional decline in older hospitalised patients. Age Ageing. 2012;41(3):381-387.

5. Hartley P, Adamson J, Cunningham C, Embleton G, Romero-Ortuno R. Clinical frailty and functional trajectories in hospitalized older adults: A retrospective observational study. Geriatr Gerontol Int. 2016.

6. Smith P, McKeon A, Blunt I, Edwards N. NHS hospitals under pressure: trends in acute activity up to 2022. London: Nuffield Trust;2014.

7. Soong J, Poots AJ, Scott S, et al. Quantifying the prevalence of frailty in English hospitals. BMJ Open. 2015;5(10):e008456.

8. Hartley P, Adamson J, Cunningham C, Embleton G, Romero-Ortuno R. Higher physiotherapy frequency is associated with shorter length of stay and greater functional recovery in hospitalized frail older adults: a retrospective observational study. J Frailty Aging. 2016;5(2):121-125.

9. Fisher SR, Kuo YF, Graham JE, Ottenbacher KJ, Ostir GV. Early ambulation and length of stay in older adults hospitalized for acute illness. Arch Intern Med. 2010;170(21):1942-1943. 
10. Mundy LM, Leet TL, Darst K, Schnitzler MA, Dunagan WC. Early mobilization of patients hospitalized with community-acquired pneumonia. Chest. 2003;124(3):883-889.

11. Jesudason C, Stiller K, McInnes M, Sullivan T. A physiotherapy service to an emergency extended care unit does not decrease admission rates to hospital: a randomised trial. Emerg Med J. 2012;29(8):664-669.

12. Smith R. Validation and Reliability of the Elderly Mobility Scale. Physiotherapy. 1994;80(11):744-747.

13. Prosser L, Canby A. Further validation of the Elderly Mobility Scale for measurement of mobility of hospitalized elderly people. Clin Rehabil. 1997;11(4):338-343.

14. Rockwood K, Song X, MacKnight C, et al. A global clinical measure of fitness and frailty in elderly people. CMAJ. 2005;173(5):489-495.

15. Charlson ME, Pompei P, Ales KL, MacKenzie CR. A new method of classifying prognostic comorbidity in longitudinal studies: development and validation. J Chronic Dis. 1987;40(5):373-383.

16. Subbe CP, Kruger M, Rutherford P, Gemmel L. Validation of a modified Early Warning Score in medical admissions. QJM. 2001;94(10):521-526.

17. Swain DG, Nightingale PG. Evaluation of a shortened version of the Abbreviated Mental Test in a series of elderly patients. Clin Rehabil. 1997;11(3):243-248.

18. Frenkel WJ, Jongerius EJ, Mandjes-van Uitert MJ, van Munster BC, de Rooij SE. Validation of the Charlson Comorbidity Index in acutely hospitalized elderly adults: a prospective cohort study. J Am Geriatr Soc. 2014;62(2):342-346.

19. Romero-Ortuno R, Wallis S, Biram R, Keevil V. Clinical frailty adds to acute illness severity in predicting mortality in hospitalized older adults: An observational study. Eur $J$ Intern Med. 2016.

20. Clyne B, Olshaker JS. The C-reactive protein. J Emerg Med. 1999;17(6):1019-1025. 
21. Povoa P, Almeida E, Moreira P, et al. C-reactive protein as an indicator of sepsis. Intensive Care Med. 1998;24(10):1052-1056.

22. Kosse NM, Dutmer AL, Dasenbrock L, Bauer JM, Lamoth CJ. Effectiveness and feasibility of early physical rehabilitation programs for geriatric hospitalized patients: a systematic review. BMC Geriatr. 2013;13:107.

23. Nolan J, Thomas S. Targeted individual exercise programmes for older medical patients are feasible, and may change hospital and patient outcomes: a service improvement project. BMC Health Serv Res. 2008;8:250.

24. Avert Trial Collaboration group, Bernhardt J, Langhorne P, et al. Efficacy and safety of very early mobilisation within $24 \mathrm{~h}$ of stroke onset (AVERT): a randomised controlled trial. Lancet. 2015;386(9988):46-55.

25. Bernhardt J, Churilov L, Ellery F, et al. Prespecified dose-response analysis for A Very Early Rehabilitation Trial (AVERT). Neurology. 2016;86(23):2138-2145.

26. Ellis G, Whitehead MA, O'Neill D, Langhorne P, Robinson D. Comprehensive geriatric assessment for older adults admitted to hospital. Cochrane Database Syst Rev. 2011(7):CD006211.

27. Bartley JM, Pan SJ, Keilich SR, et al. Aging augments the impact of influenza respiratory tract infection on mobility impairments, muscle-localized inflammation, and muscle atrophy. Aging (Albany NY). 2016;8(4):620-635.

28. Baylis D, Bartlett DB, Patel HP, Roberts HC. Understanding how we age: insights into inflammaging. Longev Healthspan. 2013;2(1):8.

29. Braun TP, Zhu X, Szumowski M, et al. Central nervous system inflammation induces muscle atrophy via activation of the hypothalamic-pituitary-adrenal axis. J Exp Med. 2011;208(12):2449-2463. 
30. Brown CJ, Friedkin RJ, Inouye SK. Prevalence and outcomes of low mobility in hospitalized older patients. J Am Geriatr Soc. 2004;52(8):1263-1270.

31. Theou O MM, Rockwood K,. How much time hospitalized older patients spend upright? Gerontologist. 2014;54(Suppl 2):S280.

32. Kortebein P, Symons TB, Ferrando A, et al. Functional impact of 10 days of bed rest in healthy older adults. J Gerontol A Biol Sci Med Sci. 2008;63(10):1076-1081.

33. Craig P, Dieppe P, Macintyre S, Michie S, Nazareth I, Petticrew M. Developing and evaluating complex interventions: the new Medical Research Council guidance. Int J Nurs Stud. 2013;50(5):587-592. 
Figure 1: Kaplan Meier curve showing proportion of patients not discharged home against length of stay (days) during the first 21 days of hospital admission

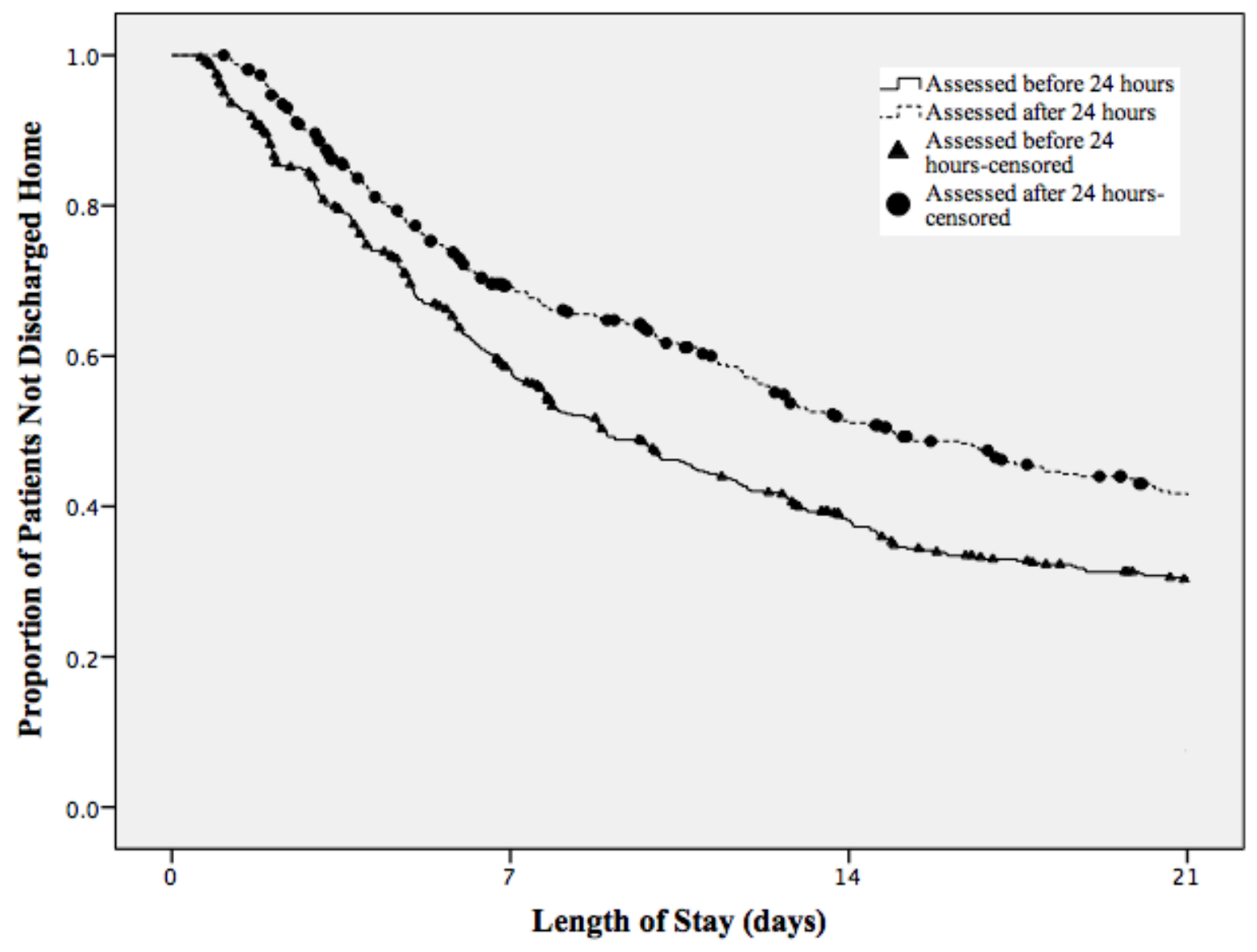


Table 1: Emergency Department Modified Early Warning Score (ED-MEWS) components and scoring

\begin{tabular}{|c|c|c|c|c|c|c|c|}
\hline Component & 3 & 2 & 1 & $\mathbf{0}$ & 1 & 2 & 3 \\
\hline HR & $<40$ & $41-50$ & $51-60$ & $61-90$ & $91-110$ & $111-129$ & $\geq 130$ \\
\hline RR & $\leq 6$ & $7-8$ & - & $9-14$ & $15-20$ & $21-29$ & $\geq 30$ \\
\hline SBP & $\leq 70$ & $71-80$ & $81-100$ & $101-180$ & - & $\geq 181$ & - \\
\hline $\begin{array}{l}\text { AVPU } \\
\text { GCS }\end{array}$ & $\mathrm{U}$ & $P$ & $\mathrm{~V}$ & $\begin{array}{l}\mathrm{A} \\
15\end{array}$ & 14 & $9-13$ & $\leq 8$ \\
\hline Temp & - & $<35 \cdot 0$ & - & $\begin{array}{l}35 \cdot 0- \\
38 \cdot 4\end{array}$ & - & $\begin{array}{l}38 \cdot 5- \\
39 \cdot 0\end{array}$ & $\geq 39 \cdot 0$ \\
\hline
\end{tabular}

Abbreviations: HR, heart rate (beats per minute); RR, respiratory rate (per minute); SBP, systolic blood pressure (mmHg); AVPU, Alert, responds to Voice, responds to Pain, Unresponsive; GCS, Glasgow Coma Scale; Temp, body temperature (degrees Celsius). Scoring and escalation protocol: minimum score $=0$ points; maximum score $=15$ points. The usual trigger for escalation (i.e. immediate referral to doctor for clinical review) is 4 or more points. 
Table 2: Comparison of baseline characteristics between the early and late assessment groups.

\begin{tabular}{|c|c|c|c|}
\hline Characteristics & $\begin{array}{l}\text { Early assessment } \\
n=584\end{array}$ & $\begin{array}{l}\text { Late assessment } \\
\mathrm{n}=419\end{array}$ & p for difference \\
\hline $\begin{array}{l}\text { Delay from } \\
\text { admission to } \\
\text { assessment (days) } \\
\text { Median (IQR) }\end{array}$ & $\begin{array}{l}0.71(0.55-0.83) \\
{[\text { missing data } n=0]}\end{array}$ & $\begin{array}{l}1.81(1.40-2.63) \\
{[\text { missing data } n=0]}\end{array}$ & $\mathrm{p}<0.001$ \\
\hline $\begin{array}{l}\text { Age } \\
\text { Mean (SD) }\end{array}$ & $\begin{array}{l}85.3(6.58) \\
{[\text { missing data } n=0]}\end{array}$ & $\begin{array}{l}85.8(7.07) \\
{[\text { missing data } \mathrm{n}=0]}\end{array}$ & $p=0.298$ \\
\hline $\begin{array}{l}\text { Female } \\
\text { Count (\%) }\end{array}$ & $\begin{array}{l}333(57.0) \\
{[\text { missing data } n=0 \text { ] }}\end{array}$ & $\begin{array}{l}240(57.3) \\
{[\text { missing data } n=0]}\end{array}$ & $p=0.935$ \\
\hline $\begin{array}{l}\text { Frailty } \\
\text { Median (IQR) }\end{array}$ & $\begin{array}{l}6(5-6) \\
{[\text { missing data } n=51]}\end{array}$ & $\begin{array}{l}6(5-6) \\
{[\text { missing data } \mathrm{n}=27]}\end{array}$ & $p=0.736$ \\
\hline $\begin{array}{l}\text { AMT4 } \\
\text { Median (IQR) }\end{array}$ & $\begin{array}{l}4(2-4) \\
{[\text { missing data } n=163 \text { ] }}\end{array}$ & $\begin{array}{l}4(2-4) \\
\text { [missing data } n=138 \text { ] }\end{array}$ & $p=0.514$ \\
\hline $\begin{array}{l}\text { ED-MEWS } \\
\text { Median (IQR) }\end{array}$ & $\begin{array}{l}3(2-4) \\
\text { [missing data } n=3 \text { ] }\end{array}$ & $\begin{array}{l}3(2-4) \\
{[\text { missing data } n=5]}\end{array}$ & $p=0.947$ \\
\hline $\begin{array}{l}\text { C-reactive protein } \\
\text { Median (IQR) }\end{array}$ & $\begin{array}{l}17.1(4.2-62.7) \\
\text { [missing data } n=42 \text { ] }\end{array}$ & $\begin{array}{l}19.9(4.6-66.5) \\
{[\text { missing data } n=30]}\end{array}$ & $\mathrm{p}=0.459$ \\
\hline $\begin{array}{l}\text { Charlson } \\
\text { Comorbidity Index } \\
\text { Median (IQR) }\end{array}$ & $\begin{array}{l}2(1-3) \\
{[\text { missing data } n=6 \text { ] }}\end{array}$ & $\begin{array}{l}2(1-4) \\
{[\text { missing data } n=6]}\end{array}$ & $p=0.464$ \\
\hline
\end{tabular}




\begin{tabular}{|c|c|c|c|}
\hline $\begin{array}{l}\text { Falls in last } 12 \\
\text { months } \\
\text { Median (IQR) }\end{array}$ & $\begin{array}{l}1(0-3) \\
{[\text { missing data } n=31]}\end{array}$ & $\begin{array}{l}1(0-3) \\
{[\text { missing data } n=37]}\end{array}$ & $\mathrm{p}=0.530$ \\
\hline $\begin{array}{l}\text { Able to walk } 6 \mathrm{~m} \text { on } \\
\text { initial assessment } \\
\text { Count (\%) }\end{array}$ & $\begin{array}{l}318(56.5) \\
\text { [missing data } n=21]\end{array}$ & $\begin{array}{l}219(56.2) \\
\text { [missing data } n=29]\end{array}$ & $\mathrm{p}=0.920$ \\
\hline $\begin{array}{l}\text { Admission walking } \\
\text { speed* (m/s) } \\
\text { Median (IQR) }\end{array}$ & $\begin{array}{l}0.31(0.20-0.45) \\
\text { [missing data } n=21]\end{array}$ & $\begin{array}{l}0.31(0.24-0.47) \\
{[\text { missing data } n=29]}\end{array}$ & $\mathrm{p}=0.435$ \\
\hline $\begin{array}{l}\text { Admission EMS } \\
\text { Median (IQR) }\end{array}$ & $\begin{array}{l}10(3-16) \\
{[\text { missing data } n=21]}\end{array}$ & $\begin{array}{l}10(4-15) \\
{[\text { missing data } n=30 \text { ] }}\end{array}$ & $\mathrm{p}=0.787$ \\
\hline $\begin{array}{l}\text { Formal package of } \\
\text { care on admission } \\
\text { Count (\%) }\end{array}$ & $\begin{array}{l}295(50.8) \\
\text { [missing data } n=3 \text { ] }\end{array}$ & $\begin{array}{l}211(50.4) \\
{[\text { missing data } n=0]}\end{array}$ & $\mathrm{p}=0.897$ \\
\hline
\end{tabular}

Abbreviations: IQR, interquartile range; SD, standard deviation; m/s, metres/second.

*only those able to mobilise $6 \mathrm{~m}$ on admission 
Table 3. Comparison of specific co-morbidities between early and late assessment groups.

\begin{tabular}{|c|c|c|c|}
\hline Condition & $\begin{array}{l}\text { Early } \\
\text { assessment } \\
n=584\end{array}$ & $\begin{array}{l}\text { Late assessment } \\
\mathrm{n}=419\end{array}$ & p for difference \\
\hline $\begin{array}{l}\text { Parkinson's } \\
\text { disease } \\
\text { Count (\%) }\end{array}$ & $\begin{array}{l}23(4.0 \%) \\
\text { [data missing } n= \\
6]\end{array}$ & $\begin{array}{l}11(2.7 \%) \\
\text { [data missing } n= \\
6]\end{array}$ & $p=0.274$ \\
\hline $\begin{array}{l}\text { Atrial } \\
\text { Fibrillation } \\
\text { Count (\%) }\end{array}$ & $\begin{array}{l}161(27.9 \%) \\
\text { [data missing } n= \\
6]\end{array}$ & $\begin{array}{l}133(32.5 \%) \\
\text { [data missing } n= \\
6]\end{array}$ & $p=0.115$ \\
\hline $\begin{array}{l}\text { Depression } \\
\text { Count (\%) }\end{array}$ & $\begin{array}{l}34(5.9 \%) \\
\text { data missing } n= \\
6]\end{array}$ & $\begin{array}{l}41(10.0 \%) \\
\text { [data missing } n= \\
6]\end{array}$ & $p=0.016$ \\
\hline $\begin{array}{l}\text { Anxiety } \\
\text { Count (\%) }\end{array}$ & $\begin{array}{l}31(5.4 \%) \\
\text { data missing } n= \\
6]\end{array}$ & $\begin{array}{l}21(5.1 \%) \\
\text { [data missing } n= \\
6]\end{array}$ & $p=0.874$ \\
\hline $\begin{array}{l}\text { Myocardial } \\
\text { Infarction } \\
\text { Count (\%) }\end{array}$ & $\begin{array}{l}71(12.3 \%) \\
\text { [data missing } n= \\
6]\end{array}$ & $\begin{array}{l}70(17.1 \%) \\
\text { [data missing } n= \\
6]\end{array}$ & $p=0.033$ \\
\hline $\begin{array}{l}\text { Congestive } \\
\text { Heart Failure }\end{array}$ & $\begin{array}{l}117(20.2 \%) \\
\text { [data missing } n=\end{array}$ & $\begin{array}{l}116(28.4 \%) \\
\text { [data missing } n=\end{array}$ & $p=0.003$ \\
\hline
\end{tabular}




\begin{tabular}{|c|c|c|c|}
\hline Count (\%) & 6] & 6] & \\
\hline $\begin{array}{l}\text { Peripheral } \\
\text { Vascular Disease } \\
\text { Count (\%) }\end{array}$ & $\begin{array}{l}37(6.4 \%) \\
\text { [data missing } n= \\
6]\end{array}$ & $\begin{array}{l}27(6.6 \%) \\
\text { [data missing } \mathrm{n}= \\
6]\end{array}$ & $\mathrm{p}=0.900$ \\
\hline $\begin{array}{l}\text { Stroke } \\
\text { Count (\%) }\end{array}$ & $\begin{array}{l}87(15.1 \%) \\
\text { [data missing } n= \\
6 \text { ] }\end{array}$ & $\begin{array}{l}61(14.9 \%) \\
\text { [data missing } n= \\
6 \text { ] }\end{array}$ & $p=0.952$ \\
\hline $\begin{array}{l}\text { Dementia } \\
\text { Count (\%) }\end{array}$ & $\begin{array}{l}108(18.7 \%) \\
\text { [data missing } \mathrm{n}= \\
6 \text { ] }\end{array}$ & $\begin{array}{l}79(19.3) \\
\text { [data missing } n= \\
6 \text { ] }\end{array}$ & $p=0.803$ \\
\hline $\begin{array}{l}\text { Chronic } \\
\text { Pulmonary } \\
\text { Disease } \\
\text { Count (\%) }\end{array}$ & $\begin{array}{l}140(28.9 \%) \\
\text { [data missing } n= \\
6]\end{array}$ & $\begin{array}{l}114(27.9 \%) \\
\text { [data missing } n= \\
6 \text { ] }\end{array}$ & $p=0.727$ \\
\hline $\begin{array}{l}\text { Connective } \\
\text { Tissue Disease } \\
\text { Count (\%) }\end{array}$ & $\begin{array}{l}38(6.6 \%) \\
\text { [data missing } n= \\
6]\end{array}$ & $\begin{array}{l}26(6.4 \%) \\
\text { [data missing } \mathrm{n}= \\
6]\end{array}$ & $\mathrm{p}=0.891$ \\
\hline $\begin{array}{l}\text { Peptic Ulcer } \\
\text { Disease } \\
\text { Count (\%) }\end{array}$ & $\begin{array}{l}3(1.0 \%) \\
\text { [data missing } n= \\
6]\end{array}$ & $\begin{array}{l}2(0.5 \%) \\
\text { [data missing } n= \\
6]\end{array}$ & $p=0.948$ \\
\hline Chronic Liver & $6(0.6 \%)$ & $1(0.2 \%)$ & $p=0.143$ \\
\hline
\end{tabular}




\begin{tabular}{|c|c|c|c|}
\hline $\begin{array}{l}\text { Disease } \\
\text { Count (\%) }\end{array}$ & $\begin{array}{l}\text { [data missing } \mathrm{n}= \\
6]\end{array}$ & $\begin{array}{l}\text { [data missing } \mathrm{n}= \\
6]\end{array}$ & \\
\hline $\begin{array}{l}\text { Diabetes (non } \\
\text { complicated) } \\
\text { Count (\%) }\end{array}$ & $\begin{array}{l}143(24.7 \%) \\
\text { [data missing } \mathrm{n}= \\
6]\end{array}$ & $\begin{array}{l}80(19.6 \%) \\
\text { [data missing } \mathrm{n}= \\
6 \text { ] }\end{array}$ & $p=0.055$ \\
\hline $\begin{array}{l}\text { Diabetes } \\
\text { (complicated) } \\
\text { Count (\%) }\end{array}$ & $\begin{array}{l}13(2.2 \%) \\
\text { [data missing } n= \\
6]\end{array}$ & $\begin{array}{l}8(2.0 \%) \\
\text { [data missing } n= \\
6]\end{array}$ & $p=0.753$ \\
\hline $\begin{array}{l}\text { Paraplegia } \\
\text { Count (\%) }\end{array}$ & $\begin{array}{l}9(1.6 \%) \\
\text { [data missing } n= \\
6]\end{array}$ & $\begin{array}{l}12(2.9 \%) \\
\text { [data missing } n= \\
6]\end{array}$ & $\mathrm{p}=0.140$ \\
\hline $\begin{array}{l}\text { Chronic Renal } \\
\text { Disease } \\
\text { Count (\%) }\end{array}$ & $\begin{array}{l}138(23.9 \%) \\
\text { [data missing } n= \\
6]\end{array}$ & $\begin{array}{l}97(23.7 \%) \\
\text { [data missing } n= \\
6]\end{array}$ & $\mathrm{p}=0.954$ \\
\hline $\begin{array}{l}\text { Cancer (non- } \\
\text { metastatic) } \\
\text { Count (\%) }\end{array}$ & $\begin{array}{l}48(7.1 \%) \\
\text { [data missing } n= \\
6]\end{array}$ & $\begin{array}{l}33(7.5 \%) \\
\text { [data missing } n= \\
6]\end{array}$ & $p=0.894$ \\
\hline $\begin{array}{l}\text { Cancer } \\
\text { (metastatic) } \\
\text { Count (\%) }\end{array}$ & $\begin{array}{l}18(3.1 \%) \\
\text { [data missing } n= \\
6]\end{array}$ & $\begin{array}{l}24(5.9 \%) \\
\text { [data missing } n= \\
6]\end{array}$ & $\mathrm{p}=0.035$ \\
\hline Severe Liver & $2(0.3 \%)$ & $0(0.0 \%)$ & $p=0.234$ \\
\hline
\end{tabular}




\begin{tabular}{|l|l|l|l|}
\hline Disease & [data missing $n=$ & [data missing $n=$ & \\
Count (\%) & $6]$ & $6]$ & \\
\hline
\end{tabular}


Table 4: Comparison of outcomes between early and late assessment groups

\begin{tabular}{|c|c|c|c|}
\hline Outcome Measures & Early assessment & Late assessment & p for difference \\
\hline $\begin{array}{l}\text { Length of Stay* } \\
\text { (days) } \\
\text { Median (IQR) }\end{array}$ & $\begin{array}{c}6.7(3.1-13.7) \\
{[\text { missing data } n=0]}\end{array}$ & $\begin{array}{c}10.0(4.2-20.1) \\
{[\text { missing data } n=0]}\end{array}$ & $p<0.001$ \\
\hline $\begin{array}{l}\text { Able to walk } 6 \mathrm{~m} \text { at } \\
\text { discharge* } \\
\text { Count (\%) }\end{array}$ & $\begin{array}{c}363(78.9) \\
{[\text { missing data } n=86]}\end{array}$ & $\begin{array}{c}253(76.9) \\
\text { [missing data } n=67]\end{array}$ & $p=0.500$ \\
\hline $\begin{array}{l}\text { Discharge walking } \\
\text { speed }^{\dagger}(\mathrm{m} / \mathrm{s}) \\
\text { Median (IQR) }\end{array}$ & $\begin{array}{c}0.33(0.21-0.51) \\
{[\text { missing data } n=86]}\end{array}$ & $\begin{array}{c}0.32(0.23-0.50) \\
\text { [missing data } n=67]\end{array}$ & $p=0.837$ \\
\hline $\begin{array}{l}\text { Discharge Elderly } \\
\text { Mobility Scale* } \\
\text { Median (IQR) }\end{array}$ & $\begin{array}{c}14(9-18) \\
{[\text { missing data } n=78]}\end{array}$ & $\begin{array}{c}14(8-17) \\
\text { [missing data } n=62]\end{array}$ & $p=0.623$ \\
\hline $\begin{array}{l}\text { Change in Elderly } \\
\text { Mobility Scale } \\
\text { discharge minus } \\
\text { admission* } \\
\text { Median (IQR) }\end{array}$ & $\begin{array}{c}0(0-3) \\
\text { [missing data } n=85]\end{array}$ & $\begin{array}{c}0(0-3) \\
\text { [missing data } n=78]\end{array}$ & $p=0.833$ \\
\hline $\begin{array}{l}\text { New } \\
\text { institutionalization* } \\
\text { Count (\%) }\end{array}$ & $\begin{array}{c}22(4.1) \\
{[\text { missing data } n=0]}\end{array}$ & $\begin{array}{c}26(6.7) \\
\text { [missing data } \mathrm{n}=0 \text { ] }\end{array}$ & $p=0.073$ \\
\hline
\end{tabular}




\begin{tabular}{|l|c|c|c|}
\hline New package of & $110(20.3)$ & $105(27.0)$ & $\mathbf{p}=\mathbf{0 . 0 1 6}$ \\
care* & [missing data $\mathrm{n}=0]$ & [missing data $\mathrm{n}=0]$ & \\
Count (\%) & & & \\
\hline Inpatient mortality & $41(7.0)$ & $30(7.2)$ & $\mathrm{p}=0.932$ \\
Count (\%) & [missing data $\mathrm{n}=0]$ & [missing data $\mathrm{n}=0]$ & \\
\hline
\end{tabular}

Abbreviations: IQR, interquartile range; SD, standard deviation; m/s, metres/second.

* excluding those who died during hospital

${ }^{\dagger}$ only those able to mobilise $6 \mathrm{~m}$ on discharge 
Table 5: Results of the Cox proportional hazards regression model

\begin{tabular}{|c|c|c|c|c|}
\hline Covariates & $\begin{array}{l}\text { Number } \\
\text { analysed }\end{array}$ & $\begin{array}{l}\text { Number of } \\
\text { 'events' }\end{array}$ & HR 95\% CI & p value \\
\hline- & 1003 & 826 & $\begin{array}{c}1.29(1.12- \\
1.48)\end{array}$ & $p<0.001$ \\
\hline Age, sex & 1003 & 826 & $\begin{array}{c}1.29(1.12- \\
1.48)\end{array}$ & $\mathrm{p}<0.001$ \\
\hline $\begin{array}{l}\text { Age, sex, ED- } \\
\text { MEWS }\end{array}$ & 995 & 820 & $\begin{array}{c}1.31(1.14- \\
1.51)\end{array}$ & $\mathrm{p}<0.001$ \\
\hline $\begin{array}{l}\text { Age, sex, ED- } \\
\text { MEWS, CCI, } \\
\text { EMS on } \\
\text { admission }\end{array}$ & 932 & 768 & $\begin{array}{c}1.34(1.16- \\
1.55)\end{array}$ & $\mathrm{p}<0.001$ \\
\hline
\end{tabular}

Abbreviations: HR, Hazzard Ratio; CI: Confidence Intervals; ED-MEWS, Emergency Department Modified Early Warning Score; CCI: Charlson Comorbidity Index; EMS, Elderly Mobility Scale; 